\title{
Fragmentos de beleza, afresco da felicidade: Entrevista com Jonas Mekas
}

\section{Fragments of beauty, fresco of happiness: Interview with Jonas Mekas}

\section{Vitor Zan}

Graduado em cinema pela UFSC, fez mestrado e doutorado em audiovisual na Universidade Paris 3. Atuou como professor provisório em diferentes universidades francesas e é professor do curso de audiovisual da UFMS. Desde 2013, realiza esporadicamente traduções para festivais, catálogos e periódicos de cinema.

Encontrei Jonas Mekas cerca de cinco vezes ao longo de minha pesquisa de mestrado, centrada em seus filmes, realizada entre 2010 e 2012, na Universidade Paris 3, com orientação de Nicole Brenez. Em duas dessas situações, tive a oportunidade de entrevistá-lo. A curta conversa que se segue ocorreu em Paris, em 2011, no início da primavera, momento do ano tão festejado na filmografia do cineasta, quando as novas folhagens e a presença de pássaros sinalizam o fim do inverno.

As questões que lhe dirigi foram constituídas em função da investigação que me mobilizava naquela época. Interessava-me estudar os diferentes laços que o cinema estabelece com a ideia de felicidade. A narrativa clássica, por exemplo, costuma ter como ponto de partida um entrave, um nó dramático, algo que impossibilita o bem-estar e que deve ser resolvido. Com efeito, no cinema comercial, o contentamento raramente se dá no presente. Ele é aquilo que se almeja, que se busca, situado num futuro para o qual a trama se dirige. Endossa-se 
assim uma perspectiva teleológica da felicidade, dialogando tanto com a noção de progresso quanto com uma tradição religiosa, cristã.

Jonas Mekas, pelo contrário, compõe afrescos através da justaposição de fragmentos de situações supostamente agradáveis e prazerosas. Seu cinema efetua gestos de celebração do presente, de instantes vivazes e belos, que se dão aqui e agora, deixando de fora aquilo que nesse presente poderia ser problemático. 0 tempo da gravação é o instante atual, o glimpse, mas o tempo da retomada dos arquivos e dos comentários em off é outro e, por vezes dilui nostalgia no pano de fundo. Como entender, por esse prisma da felicidade, a textura envelhecida das imagens, os efeitos de aceleração, trepidação e superexposição?

Se por um lado há ruptura, por outro há continuidade, interferências e reverberações. Pois a obra de Jonas Mekas repõe elementos de figurações tradicionais da felicidade. Retoma uma série de motivos do imaginário edênico constituído pela Igreja na Idade Média e remete a mitos da Antiguidade, que situam o júbilo num passado longínquo; num paraíso perdido não no espaço, mas no tempo, e do qual alguns vestígios ainda são perceptíveis.

Em diálogo com essas tradições seculares, mas também com pensamentos e estilos do underground estadunidense dos anos 1960, e ainda com a cultura lituana de sua juventude, Jonas Mekas elabora formulações e figurações próprias acerca da felicidade, que são indissociáveis de sua prática cinematográfica e emanam de seu cinema. A entrevista a seguir se enquadra na tentativa de entendê-las, muito embora, em minha pesquisa, a maior parte desse esforço tenha se concentrado no corpo a corpo com os filmes. Sem motivo convincente, num gesto um pouco mekasiano, deixei o material repousar por quase dez anos antes de me dar o tempo de traduzi-lo e publicá-lo.

Vitor Zan

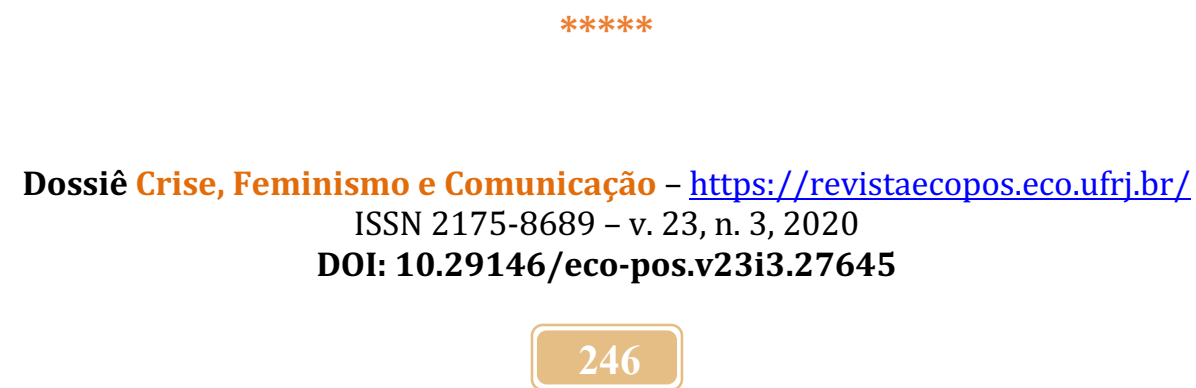




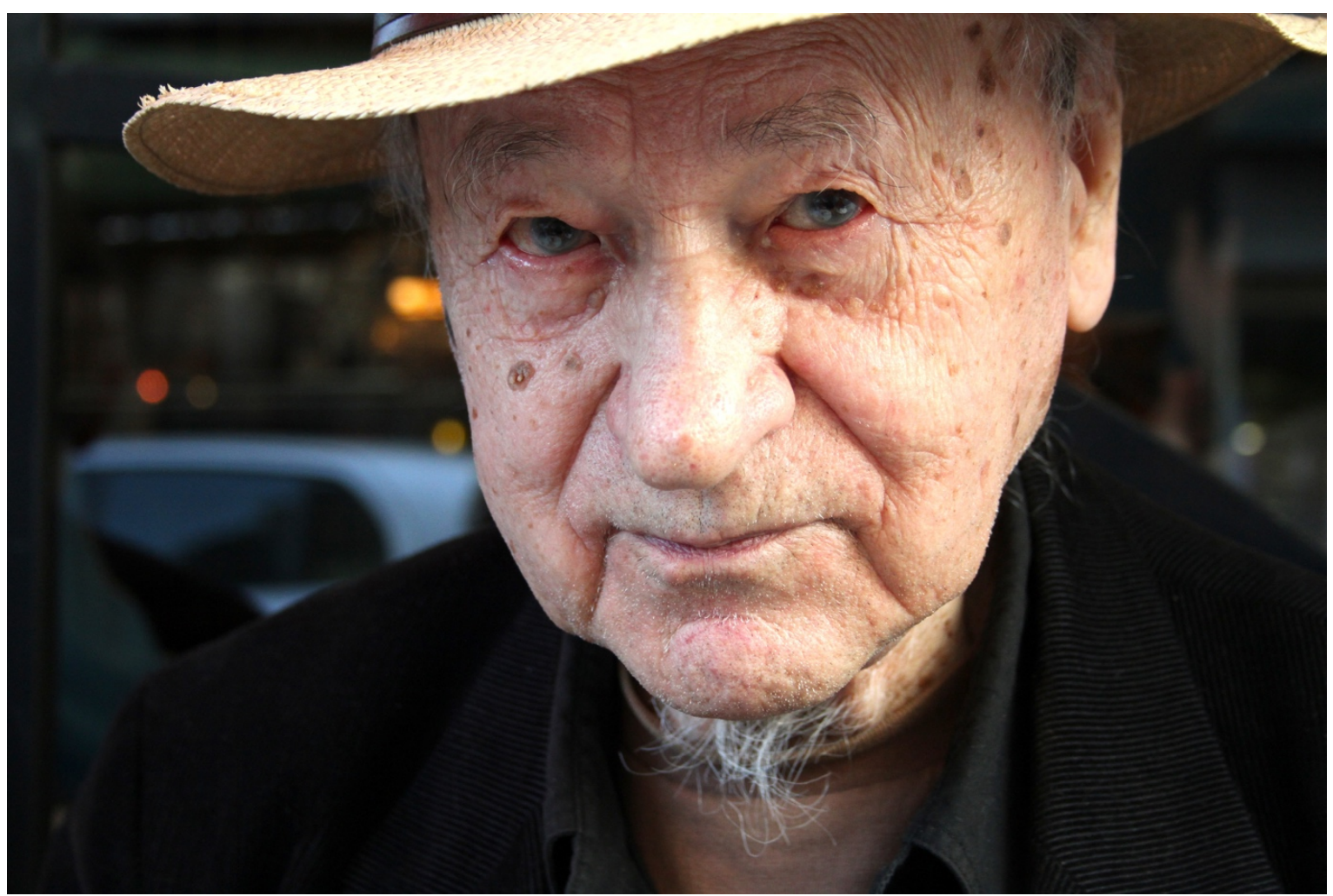

FIG. 1: Jonas Mekas, Fonte: Foto tirada pelo entrevistador durante a reunião

Vitor Zan (V.Z.): Meu primeiro contato com sua obra foi através do filme As I Was Moving Ahead Occasionally I Saw Brief Glimpses of Beauty (2000). Foi marcante a experiência dos lampejos fragmentários de sua vida íntima, de sua relação com amigos, dos motivos da natureza e das cidades. Por isso, se me permite, gostaria de começar por aí. Poderia contar sobre as origens desse projeto?

Jonas Mekas (J.M.): Claro. A origem desse filme é extremamente simples. Eu tinha um grande volume de material arquivado e sabia que o tempo estava apagando as cores das bobinas. 0 celuloide da película não é eterno. Eu precisava fazer algo rapidamente com esse material. Na época, eu estava de passagem por Avignon quando os organizadores de uma grande exposição me convidaram para fazer um

Dossiê Crise, Feminismo e Comunicação - https://revistaecopos.eco.ufrj.br/

ISSN 2175-8689 - v. 23, n. 3, 2020

DOI: 10.29146/eco-pos.v23i3.27645 
filme. 0 tema geral da exposição era nada menos que o belo, e o evento fazia parte de uma série de comemorações da chegada do ano 2000. Eles disseram que arcariam com os custos de laboratório, o que realmente fizeram. Era a oportunidade que eu precisava para retomar os arquivos e fazer algo com eles. 0 material cobre cerca de vinte e cinco anos da minha vida. Foi simples assim. A película estava estragando, eu tinha que inventar algo, e de repente surgiu o dinheiro para viabilizar a empreitada. A feitura dos meus filmes sempre tem razões muito práticas, pé no chão, com limitações e motivações bastante simples.

V.Z.: Então a gênese do projeto tem um pouco a ver com a virada de século e com a experiência do belo. Isso me faz pensar num poema que você publicou em seu site, A Requiem for the XXth Century (2000). Nele, você evoca brevemente os horrores do século XX. Diz esperar que eles nunca retornem, mas também ressalta os momentos de alegria e de graça que cada um pôde experimentar. Você escreve ainda que segue acreditando nas coisas belas e simples que são consideradas insignificantes e inúteis. Segundo o poema, essas coisas compõem sua própria ideia de paraíso, de Walden ${ }^{1}$. Tenho a impressão de que isso perpassa quase todos os seus filmes, que retomam, incansavelmente, imagens e motivos admirados, celebrados, através dos quais uma forma de felicidade é afirmada.

J.M.: De fato, não estou interessado em aspectos deprimentes da humanidade. Deixo isso para outros artistas. Há muitos artistas focados unicamente no lado obscuro da vida, em coisas horríveis e decadentes. Eu sou pela celebração da amizade, da felicidade e de todos os aspectos alegres da humanidade que ainda existem. Porque isso não é considerado como um tema para esses artistas. Eles

1 Nota do tradutor. Walden é o primeiro filme-diário de Jonas Mekas que obteve respaldo internacional. Seu título faz alusão ao livro homônimo do transcendentalista estadunidense Henry David Thoreau, no qual o autor restitui experiências vividas ao longo dos dois anos que passou isolado em meio à natureza. Jonas Mekas encontra nesses escritos o imaginário idílico de sua infância na Lituânia, o elogio à simplicidade, bem como o tipo de expressão "direto", em primeira pessoa, que caracteriza seus filmes. No léxico do cineasta, "Walden" representa a possibilidade de nos conectarmos, em nossas experiências concretas, com elementos paradisíacos.

Dossiê Crise, Feminismo e Comunicação - https://revistaecopos.eco.ufrj.br/

ISSN 2175-8689 - v. 23, n. 3, 2020

DOI: 10.29146/eco-pos.v23i3.27645 
acham que isso é sentimental. Deveríamos ser mais minimalistas. Não sou um artista da abstração. Meus filmes são muito concretos: são sobre pessoas e situações.

V.Z.: Se a ideia de felicidade, ou mesmo de paraíso, de Walden, é importante para você, me parece que seus filmes não forjam um universo edênico conforme o imaginário religioso. Parecem se esforçar para reunir os fragmentos de um possível paraíso enxergado na vida cotidiana, na cidade, nas ruas, no Central Park, ou pelo menos no cinema.

J.M.: Talvez devêssemos realmente encontrar um outro lugar para ele. Acredito em Walden, nos campos e nas cidades, nas coisas pequenas. São esses momentos que eu chamo de "beleza" (beauty). Eles precisam de mais proteção que as coisas horríveis. A eles dedico meus diários. Assistir e viver dentre imagens do horror acabam com você. Considero que mais vale viver rodeado e invadido por belos aspectos da natureza, das canções, das amizades, e da felicidade. Essa é minha postura. Você pode fazer o que quiser, mas esse é meu posicionamento. É nisso que eu acredito.

V.Z.: Você acredita que esse ponto de vista tem a ver com os valores e crenças de suas origens lituanas? Você escreveu em seu diário que a cristianização não foi totalmente bem-sucedida na Lituânia.

J.M.: Sim. Hoje em dia a Lituânia é bem cristã. Mas ainda hoje são preservados no Vaticano documentos do século XIX nos quais bispos católicos reclamam e demonstram até certo pânico com o fato de a Lituânia continuar sendo um país pagão, onde as pessoas acreditam em árvores sagradas, cobras e todos esses elementos do panteísmo. 
V.Z.: Em sua juventude, você vivenciou essa fé na natureza, em animais, árvores e símbolos?

J.M.: Eles não eram símbolos, eram sagrados! Sim, eram sagrados. Quando eu era criança, a maior parte disso já havia desaparecido, mas a admiração e o respeito pela natureza estão lá até hoje. Algo dessa cultura panteísta ainda era forte na minha infância e continua sendo atualmente.

V.Z.: De que forma você acha que seu trabalho está relacionado a sua cultura de origem, do interior da Lituânia?

J.M.: Com certeza há relações, mas é difícil dizer quais. Meu trabalho é mais antropológico. Filmo o que está diante de mim, capturo esses momentos de humanidade. Às vezes tenho êxito, às vezes não, mas esse exercício me deixa mais consciente e atento aos eventos; ao que está se passando, aqui e agora.

V.Z.: Mudando um pouco de assunto, a partir da decisão de apontar a câmera para elementos do mundo que te agradam, você não pretende restituir um olhar naturalista, "transparente". Pelo contrário, realiza uma série de operações visuais que chamam a atenção do espectador para a própria plasticidade das imagens. Se por um lado você é um cineasta do real, com certo viés documental, por outro é também um artista do artifício, do experimentalismo. Gostaria que falasse um pouco do aspecto técnico de seus filmes: dos efeitos de flash, trepidação, aceleração, etc.

J.M.: Estamos falando sobre o período em que eu filmava com uma Bolex. Nessa época, eu não captava sons. Eram filmagens "silenciosas", e cada take tinha no máximo dezoito segundos. Mas também era possível registrar single frames, trabalhar com subexposição e superexposição. Podia-se ainda fazer sobreposições,

Dossiê Crise, Feminismo e Comunicação - https://revistaecopos.eco.ufrj.br/

ISSN $2175-8689$ - v. 23, n. 3, 2020

DOI: 10.29146/eco-pos.v23i3.27645 
nas quais um take é registrado por cima de outro. Há muitos truques e colagens nos meus filmes feitos com a Bolex.

\section{V.Z.: Parte desses efeitos é produzida após as filmagens?}

J.M.: Não, tudo ocorre durante a filmagem, tudo. Não há nenhuma pós-produção nesse sentido. São estratégias muito simples, como mudar a velocidade do shutter, alterar bruscamente a abertura do diafragma, coisas assim. A Bolex é uma câmera muito precisa em muitos sentidos.

V.Z.: Em alguns trechos de seus filmes, tenho a impressão de que você usa a câmera como um disparador de brincadeiras. Ao invés de intimidar aqueles que estão diante da câmera, você usa o aparelho para promover descontração compartilhada. Chego a pensar no seu instrumento de trabalho como uma "câmera-brinquedo". Como você enxerga isso?

J.M.: Eu sempre fui uma pessoa tímida, antes mesmo de chegar aos Estados Unidos. A câmera me permite participar mais diretamente das situações e fazer isso de forma divertida. Também uso a câmera como forma de concentrar toda minha atenção no presente, naquilo que se sucede ao redor de mim. Reajo ao que acontece. Se filmo crianças, tento ser como uma criança. Senão estaria fazendo algo distanciado, objetivo, e eu não sou esse tipo de pessoa. Mergulho nas situações, me confundo com elas. Se filmo um cachorro, me torno um cachorro, ou seja, tento ser parte daquilo que estou registrando.

\section{V.Z.: Você pensa sobre a recepção de seus filmes ao fazê-los?}

J.M.: Não, não posso pensar nisso. Faço filmes para mim mesmo e para meus amigos. Não penso nos outros, porque também considero os outros meus amigos.

Dossiê Crise, Feminismo e Comunicação - https://revistaecopos.eco.ufrj.br/

ISSN 2175-8689 - v. 23, n. 3, 2020

DOI: 10.29146/eco-pos.v23i3.27645 
Somos todos humanos, então aquilo que Benn [Northover] ou Pip [Chodorov] enxergarão, outras pessoas poderão enxergar. Eles notarão algumas particularidades por me conhecerem melhor, mas basicamente todos nós reagimos mais ou menos da mesma forma diante das mesmas situações.

\section{V.Z.: Seus filmes são feitos para serem vistos sem interrupção?}

J.M.: Por mim tudo bem se alguém quiser assistir apenas a alguns trechos. Mas também é possível unir todos os meus filmes e entendê-los como uma única obra. 